\title{
A Pioneer Case Study on Identification of Infant Rhinoceros Horn
}

\author{
Dinesh Kumar Jha*, Sandeep Kumar Gupta, Nirajan Thapa Kshetry, Raju Panday and Basanta Raj Pokharel \\ National Forensic Science Laboratory Biology, Khumaltar, Lalitpur, Kathmandu, Nepal \\ *Corresponding author: Dinesh Kumar Jha, Chief Scientific Officer, National Forensic Science laboratory Biology, Khumaltar, Lalitpur, Kathmandu, Nepal, Tel: \\ 977-1-5526927; Fax: 713-500-5495; E-mail: dineshkjha@hotmail.com
}

Received date: February 19, 2017; Accepted date: March 05, 2017; Published date: March 11, 2017

Copyright: () 2017 Jha DK, et al. This is an open-access article distributed under the terms of the Creative Commons Attribution License, which permits unrestricted use, distribution, and reproduction in any medium, provided the original author and source are credited.

\begin{abstract}
Objective: To investigate the authenticity of infant Rhino horn sample from morphometric, microscopic, genetic and phylogenetic studies.

Methods: A suspected rhino horn sample $(11 \mathrm{~cm} \times 13 \mathrm{~cm})$ was sent to the laboratory for identification. Relevant morphometric data of sample were taken. Similarly, established methods for microscopic examination of rhino horn were adopted. Using standard universal primer, a part of Cytochrome b (Cyt b) and 12S rRNA was amplified from sample, sequenced and aligned using BLAST of the GenBank (NCBI) and in-house reference database available at Wildlife Institute of India, Dehradun, India for decisive confirmation of species.
\end{abstract}

Results: Morphometric analysis showed the sample was oval, dome shaped with a bony part which was supported by upper skin. Presence of filamentous units is the microscopic identifying feature of genuine rhino horn. However, microscopic examination showed very unclear filamentous units because of the immature nature of sample. Mitochondrial sequence data revealed the source of suspected sample was of a one-horn Rhinoceros (Rhinoceros unicornis). Similarly, NJ method for phylogenetic analysis for both Cytb and 12S rRNA identified sequence similarity with Rhinoceros unicornis.

Conclusion: Even though the morphometric and microscopic data do not reveal much about the infant rhino horn, mtDNA sequencing used in this pioneer study can be applied in the wildlife forensic for identification of such parts in future and data used as evidence against the poachers in the court of law.

Keywords: Infantile rhino horn; Forensic science; Filamentous unit; Cyt b; $12 S$ rRNA; BLAST; Neighbour- joining method

\section{Introduction}

Wildlife and their products represent the third greatest illegal traffic after drugs and arms [1]. Illegal poaching are threats to a wide range of endangered species around the world [2]. Many species are protected both at a national and international level and their conservation requires control of illegal poaching [3]. Concept of "species" is perhaps the most debated subject in evolutionary biology [4]. But accurate identification of the species from confiscated biological material is of paramount importance to the investigation of crime in forensics [5], fixing the accurate wildlife offence [6] and so as to prove the conviction of crime by offenders [7]. The test employed depends on the material seized and the available techniques [3]. Morphology and microscopy are the natural starting points in identification [8]. However, the morphological examination has some limitations especially when material is present as powders, potions, oils [3], examination from old, degraded [9], partial, small parts [7] or processed, tanned, finished wildlife products [10]. Currently, DNA sequencing analysis is the proven and most reliable method used for species identification from confiscated biological samples [7]. A number of case reports have shown the usefulness of DNA analysis for solving cases including endangered species [11-20].

Material suspected of originating from Rhinoceros is frequently seized by forensic organizations especially in parts of Asia where the rhinoceros horns are used traditionally [21]. A suspected rhino horn sample was sent to our laboratory for identification. A variety of methods are available to characterize a genuine rhino horn and its products [22]. However, usual morphological and microscopic techniques were inappropriate because of the nature of suspected sample. In this pioneer article, we report the successful identification of ambiguous infant rhinoceros horn through the combined application of mitochondrial Cytochrome b (Cyt b) and $12 S$ rRNA gene sequence analysis and microscopic examination. The procedure can be used by scientific community and data used as evidence against the poachers to convict the wildlife crime in the court of law.

One-horned rhinoceros (Rhinoceros unicornis) inhabiting primarily in India and Nepal is included in Appendix I of the CITES. This species is also listed in schedule I of the Nepal Government's National Parks and Wildlife Conservation Act 1973 and in Indian Wildlife (Protection) Act 1972. As per provision in the Act, any person found guilty of possessing, selling or buying Rhinoceros horn or other body parts is subject to a fine of NRs. 50,000 to 100,000 (1USD 105NRs) or 3-15 years of imprisonment or both. Rhino horn seemed to be world's most valuable substance and thus its illicit trade has been steadily increasing with different purposes including ritual, medicinal and recreational activities [22]. In Nepal, horn bearing nasal part below the three years age of Rhinoceros is locally called Brahma-khaag (Brahma-Hindu creator god, Khaag-Rhino horn) which has notable religious value. 


\section{Methods}

\section{Case history}

The Department of National Parks and Wildlife Conservation, Babarmahal, Nepal had received a suspicious rhino horn sample. The sample was sent to our laboratory to identify the confiscated samples and if possible species identification also.

\section{Morphometric examination}

The overall shape, surface texture and configuration of sample were studied and measurements taken.

\section{Microscopic examination}

Thin transverse sections from the apex and margin of the sample skin were randomly taken with the help of a sharp razor blade. The sections were cleansed with xylene, dried, mounted in a clean microscopic slide with DPX and observed under 200X using light microscope (Olympus CX41 RF, Japan). A previously developed methodology was adopted to study the internal microscopic structure of hair [23].

\section{DNA extraction and PCR}

Approximately $100 \mathrm{mg}$ skin piece was used for the extraction of DNA using standard protocol [24] in $100 \mu \mathrm{L}$ extraction volume. The isolated DNA was amplified using the universal PCR primers: mcb398, 5'-TACCATGAGGACAAATATCATTCTG-3' and mcb869, 5'CCTCCTAGTTTGTTAGGGATTGATCG-3' [5] as well as conserved primers: $\quad 12 \mathrm{~S} \quad$ rRNA-F_L1091, GCTTCAAACTGGGATTAGATACCCCAC and 12S rRNA-R_H1478, TGACTGCAGAGGGTGACGGGCGGTGTGT [25] targeting the mitochondrial $C y t b$ and $12 S r R N A$ gene respectively. The use of universal primers minimizes the effort of researcher, since it can be applied for PCR amplification to the DNA of all species without prior information of the victim species [26].

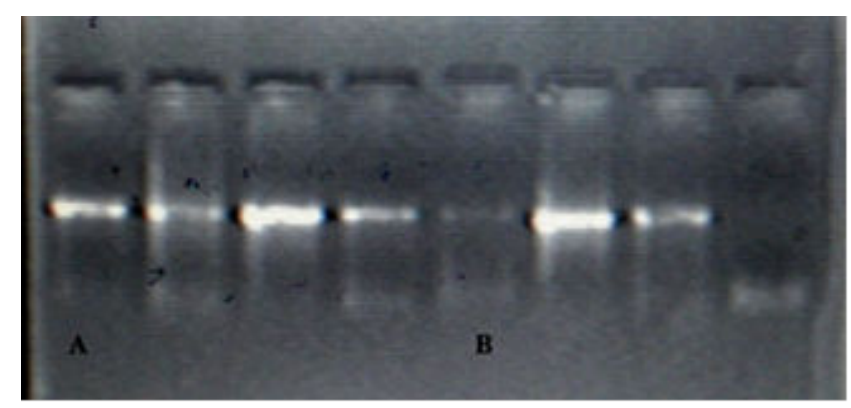

Figure 1: PCR amplification product of $12 S$ rRNA (Lane A) and $C y t$ $b$ gene (Lane B) electrophored in $2 \%$ agarose gel.

The PCR reaction mixture was prepared in a dedicated laminar hood. PCR amplification was performed in a Veriti thermal cycler (Applied Biosystems, Singapore) in a final volume of $10 \mu \mathrm{L}$ containing $1 \mu \mathrm{L}$ of the extracted DNA, $0.2 \mu \mathrm{L}$ of forward primer $(5 \mathrm{pmol})$ and 0.2 $\mu \mathrm{L}$ of forward primer (5 pmol), $1 \mu \mathrm{L}$ of $10 \mathrm{X}$ buffer, $0.6 \mu \mathrm{L}$ of Magnesium chloride $(3.0 \mathrm{mM}), 1 \mu \mathrm{L}$ Bovine serum albumin $(2 \mathrm{mg} / \mathrm{ml})$, $0.2 \mu \mathrm{L}$ dNTPs $(2.5 \mathrm{mM}), 0.2 \mu \mathrm{L}$ Taq polymerase (5 units/ $\mu \mathrm{L})$ and 5.6 $\mu \mathrm{L}$ Double distilled water. The PCR conditions were as follows: an initial denaturation at $95^{\circ} \mathrm{C}$ for $3 \mathrm{~min}$, followed by 35 cycles of denaturation at $95^{\circ} \mathrm{C}$ for 35 seconds, primer annealing at $53^{\circ} \mathrm{C}$ for 45 seconds, primer extension at $72^{\circ} \mathrm{C}$ for 40 seconds. The final extension was at $72^{\circ} \mathrm{C}$ for $10 \mathrm{~min}$. Negative PCR control was subjected to amplification. The PCR products obtained were electrophoresed on $2 \%$ agarose gel, stained with ethidium bromide, and visualized under a UV transilluminator to assess amplification (Figure 1).

\section{Post PCR clean-up and DNA sequencing}

The PCR product obtained was treated with Exonuclease I (Exo I) and Shrimp Alkaline Phosphatase (SAP) to clean the unused primers and dNTPs. $1.5 \mu \mathrm{L}$ of PCR product was directly incubated with $0.5 \mu \mathrm{L}$ ExoSAP at $37^{\circ} \mathrm{C}$ for $20 \mathrm{~min}$. followed by inactivation of enzymes at $85^{\circ} \mathrm{C}$ for $15 \mathrm{~min}$. The PCR product after Exo-I and SAP treatment was cycle sequenced. PCR amplification was performed in a Veriti thermal cycler in a final volume of $10 \mu \mathrm{L}$ containing $2.0 \mu \mathrm{L}$ of ExoSAP and PCR products, $1 \mu \mathrm{L}$ of Big dye $5 \mathrm{X}$ sequencing buffer, $0.5 \mu \mathrm{L}$ of Big dye RR mix v 3.1, $0.2 \mu \mathrm{L}$ of Primer (Forward only) and $6.3 \mu \mathrm{L}$ of double distilled water. The PCR conditions were as follows: an initial denaturation at $96^{\circ} \mathrm{C}$ for $5 \mathrm{sec}$, followed by 28 cycles of denaturation at $96^{\circ} \mathrm{C}$ for 10 seconds, primer annealing at $50^{\circ} \mathrm{C}$ for $5 \mathrm{sec}$, primer extension at $60^{\circ} \mathrm{C}$ for $4 \mathrm{~min}$. Sequencing reaction products were purified by Sodium acetate ethanol precipitation method and detected by an ABI 3500xL Genetic Analyzer (Applied Biosystems, USA).

\section{Data analysis}

Quality of sequences was determined using Sequencing Analysis software v 6.0 (Applied Biosystem). Further Multiple Sequence Alignments (MSA) was performed by CLUSTAL W algorithm implemented in BIOEDIT version 7.0.9.0 [27]. The obtained consensus sequence was compared with sequences available on public domain at GenBank (http://blast.ncbi.nlm.nih.gov/) using BLAST [28] and in a "in-house database" available in Wildlife Institute of India, Dehradun, India. Phylogenetic trees including all the aligned sequences for the $C y t b$ and $12 S$ rRNA genes were generated based on Kimura 2 parameter model for nucleotide substitution with 1000 bootstrap values replications using the Neighbor-joining (NJ) method [29] as implemented in MEGA v 5.1 software [30].

\section{Results and Discussions}

\section{Morphometry}

Suspected sample was oval, dome shaped, bony part supported by upper skin (Figure $2 \mathrm{a}$ and $2 \mathrm{~b}$ ). The measured size, height and circumference were $11 \times 13,4.0$ and $25 \mathrm{~cm}$ respectively. Periphery of the horn was rough while the centre was smooth. Maximum thickness of skin measured was $0.81 \mathrm{~cm}$. Ventral surface had frequent bony elevations (Figure 1c). Fewer black, short, coarse hairs were observed at the margins only (Figure 1b). Overall, these findings indicated that sample was skull or skull part of a big mammal. Hence, possibility of rhinoceros skull part, especially nasal part of immature ones was not debarred. Rhino horn is anchored to the dermis covering the frontal and nasal bones [31]. Authentic rhinoceros skull was unavailable in the laboratory. Thus, a definite conclusion about the sample was not possible from the morphological data only. Morphological examination has limitations especially when reference sample from known source is unavailable [6]. Identification of the suspected 
Citation: Jha DK, Gupta SK, Kshetry NT, Panday R, Pokharel BR (2017) A Pioneer Case Study on Identification of Infant Rhinoceros Horn. J

Page 3 of 6

rhinoceros material in the absence of morphological uniqueness is problematic [21]. No any visual evidence of a Rhino horn was observed in the sample. This is probably because a rhinoceros calf is born hornless [32]; pierce the skin at 5 weeks, $39 \mathrm{~mm}$ long at 3 months and $100 \mathrm{~mm}$ long at 7 months [33].

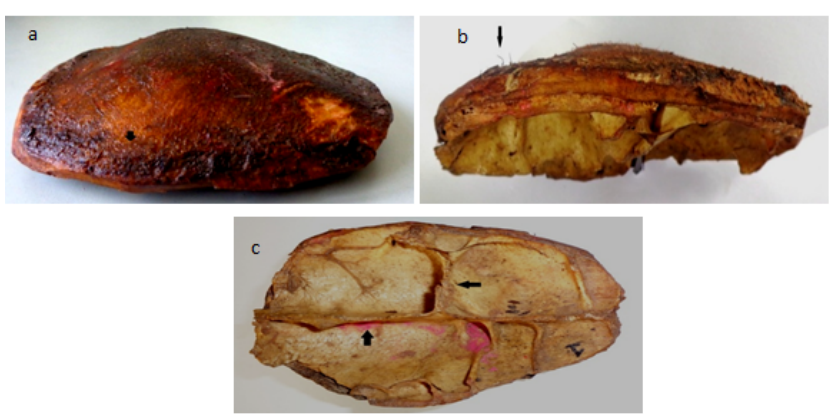

Figure 2: Dorsal (a), Lateral (b) and ventral (c) view of sample. Section site (a), hair (b) and bony elevations (c) indicated by arrow.

\section{Microscopic findings}

The occurrence of filamentous units and laminae is the microscopic identifying feature of genuine rhino horn [22]. In microscopic examination, section from margin of sample showed indistinct filamentous units, laminae with larger filamentous spaces (Figure 3).

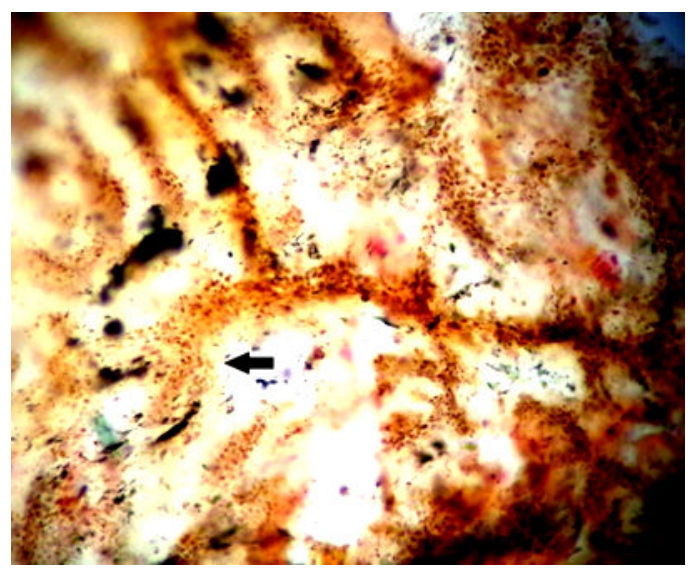

Figure 3: Microscopic structure of section (Filamentous units/ laminae indicated by arrow).

This is probably due to immaturity of horn. Immature horns have greater filamentous units space in comparison to matured rhino horn [22]. Presence of these microscopic identifying features over the skin surface strongly indicated sample as an infant rhinoceros nasal part that bears horn.

Species identification based on hair characteristics has been widely used in dealing the wildlife offence [34]. However, medulla and other specific characteristics were not observed in the hair except profound pigment granules (Figure 4). The maximum measured length and diameter of hair was $5 \mathrm{~mm}$ and $150 \mu \mathrm{m}$ respectively.

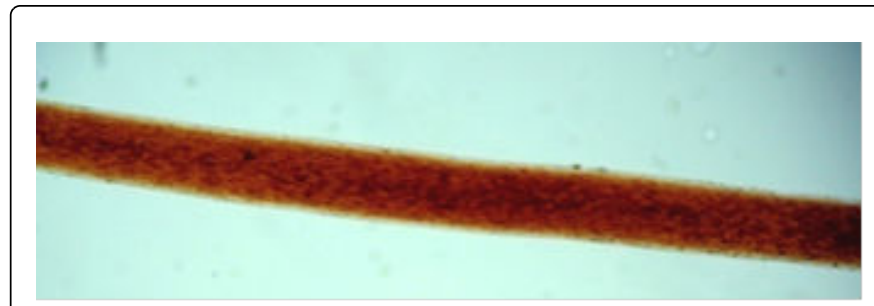

Figure 4: Microscopic configuration of hair (100X magnification).

\section{Genetic analysis}

Mitochondrial DNA (mtDNA) is most commonly used in species identification and attracts researchers because of its compact size, high copy number per cell, maternal inheritance, absence of introns and pseudogenes and fast evolutionary rate [35-38]. Cyt b, cytochrome oxidase I (COI), two ribosomal RNA (12S rRNA and $16 \mathrm{~S}$ rRNA), the control region (D-loop) and subunits of mitochondrial encoded $\mathrm{NADH}$ dehydrogenase gene are the widely deployed mitochondrial gene for species identification in wildlife forensic [39].

\begin{tabular}{|c|c|c|c|c|}
\hline \multirow[b]{2}{*}{$\begin{array}{l}\text { Species/ } \\
\text { Subspecies }\end{array}$} & \multicolumn{2}{|c|}{ Cyt b (187 bp) } & \multicolumn{2}{|c|}{ 12S rRNA (140 bp) } \\
\hline & $\begin{array}{l}\text { Accession } \\
\text { Number }\end{array}$ & $\begin{array}{l}\text { Similarity } \\
(\%)\end{array}$ & $\begin{array}{l}\text { Accession } \\
\text { Number }\end{array}$ & Similarity (\%) \\
\hline $\begin{array}{l}\text { Rhinoceros } \\
\text { unicornis }\end{array}$ & JN935370.1 & 100 & $\begin{array}{l}\text { AY739618. } \\
1\end{array}$ & 100 \\
\hline $\begin{array}{l}\text { Rhinoceros } \\
\text { sondaicus }\end{array}$ & AJ245725.1 & 87 & $\begin{array}{l}\text { AJ245724. } \\
1\end{array}$ & 98 \\
\hline $\begin{array}{l}\text { Rhinoceros } \\
\text { sondaicus } \\
\text { sondaicus }\end{array}$ & - & - & $\begin{array}{l}\text { AY739620. } \\
1\end{array}$ & 98 \\
\hline $\begin{array}{l}\text { Rhinoceros } s . \\
\text { annamiticus }\end{array}$ & - & - & $\begin{array}{l}\text { AY739619. } \\
1\end{array}$ & 98 \\
\hline $\begin{array}{l}\text { Diceros bicornis } \\
\text { minor }\end{array}$ & - & - & $\begin{array}{l}\text { FJ608808. } \\
1\end{array}$ & 98 \\
\hline $\begin{array}{l}\text { Coelodonta } \\
\text { antiquitatis }\end{array}$ & GU371439.1 & 86 & - & - \\
\hline $\begin{array}{l}\text { Dicerorhinus } \\
\text { sumatrensis }\end{array}$ & AJ245723.1 & 85 & $\begin{array}{l}\text { AJ245722. } \\
1\end{array}$ & 97 \\
\hline $\begin{array}{l}\text { Dicerorhinus } \\
\text { sumatrensis }\end{array}$ & - & - & $\begin{array}{l}\text { AY739616. } \\
1\end{array}$ & 97 \\
\hline $\begin{array}{l}\text { Ceratotherium } \\
\text { simum simum }\end{array}$ & FJ619038.1 & 85 & $\begin{array}{l}\text { FJ608805. } \\
1\end{array}$ & 96 \\
\hline $\begin{array}{l}\text { Ceratotherium } \\
\text { simum cottoni }\end{array}$ & FJ619039.1 & 84 & $\begin{array}{l}\text { FJ608806. } \\
1\end{array}$ & 97 \\
\hline
\end{tabular}

Table 1: Details of used species/subspecies and their GenBank Accession number of $C y t b$ and $12 S$ r RNA gene.

The central concept in species identification is to match the sequence of the evidence item to a reference sequence, either through DNA sequence similarity searches [40] or by phylogenetic reconstruction [41]. In sequence matching approach, a measure of the similarity between sequences is calculated and the most similar species is attributed to the sample $[42,43]$ A 187 bp consensus sequence of Cyt 
Page 4 of 6

b was obtained from confiscated sample and a sequence similarity search performed in GenBank provided the highest similarity (100\%) with Rhinoceros unicornis (NCBI Accession JN935370) i.e. an Asiatic one-horned Rhinoceros, whereas, it had $87 \%$ sequence similarity with Rhinoceros sondaicus (NCBI Accession: AJ245725) followed by other Rhinoceros species/subspecies with a decreasing sequence similarity (Table 1). Similarly, 140 bp consensus sequences of $12 \mathrm{~S}$ rRNA was obtained which also showed highly similarity (100\%) to the Rhinoceros unicornis (NCBI Accession: AY739618) with reference sequence (Table 1).
Sequence comparisons identified a total of 48 and 8 variable sites for Cyt $b$ and $12 S$ rRNA respectively. This indicates Cyt b sequences of confiscated sample had higher variability with nearby species/ subspecies comparison to $12 \mathrm{~S}$ rRNA sequence. Appropriate Genetic DNA markers are those which are rather conservative within the species but discriminative between the species [44]. Cyt b shows limited variability within and much greater variation between species [45] thus ideal for species identification [42].

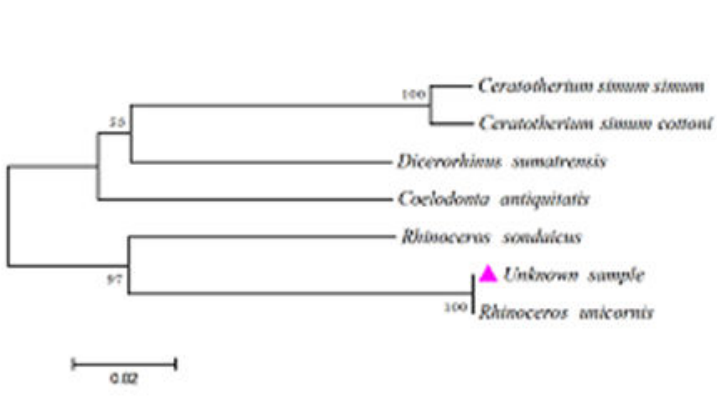

(a)

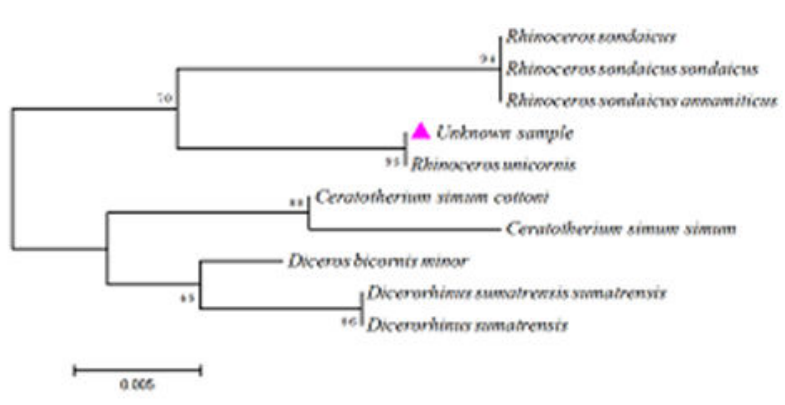

(b)

Figure 5: Neighbour-Joining phylogenetic tree based on Cyt b (a) and 12S rRNA (b) showing the relationships of unknown sample with the other related species/subspecies of rhinoceros available in GenBank.

The phylogenetic tree is used to discern the evolutionary relationships between the suspected sample and reference sequences from each possible species $[5,46,47]$. The position of the suspected sample in the tree allows the closest reference species to be identified as the likely source [7]. There are several different methods for constructing phylogenetic trees (e.g. neighbor-joining, maximum parsimony, maximum likelihood and Bayesian [7,48]. But, there is currently no consensus in wildlife forensic science over which to use $[49,50]$ The neighbor-joining (NJ) phylogenetic tree showed that BLAST analysis and neighbor-joining bootstrap values are similar in $C y t b$ gene. The NJ trees constructed using the sequences of $C y t b$ gene showed the similarity of confiscated sample to Rhinoceros unicornis with $100 \%$ bootstrap values (Figure $5 \mathrm{a}$ ). The NJ tree made from sequences of $12 S$ rRNA gene also produced strong weight for the genetic similarity of suspected sample with Rhinoceros unicornis (Figure 5b).

Reference sequence database of different species those are highly in wildlife trades are available at Wildlife Institute of India [51] and such data was used to confirm the BLAST results. Sequences of the $12 \mathrm{~S}$ $r R N A$ genes was aligned with the reference database of WII and constructed NJ trees showed the similarity of confiscated sample to Rhinoceros unicornis with $100 \%$ bootstrap values (Figure 6). This is required because The International Society of Forensic Genetics (ISFG) recommends the use of voucher specimen reference DNA sequence, an inhouse and authentic DNA database for species identification for forensic validation [52]. The most commonly used reference databases for comparative species identification searches are the NCBI/EMBL/ DDBJ database collaboration and BOLD [7]. Much of the initial sequence data held on BOLD are unauthenticated, limited regulation and erroneous sequences [53-56]. This can lead to false identifications if the target sample belongs to a previously uncharacterized species [57].

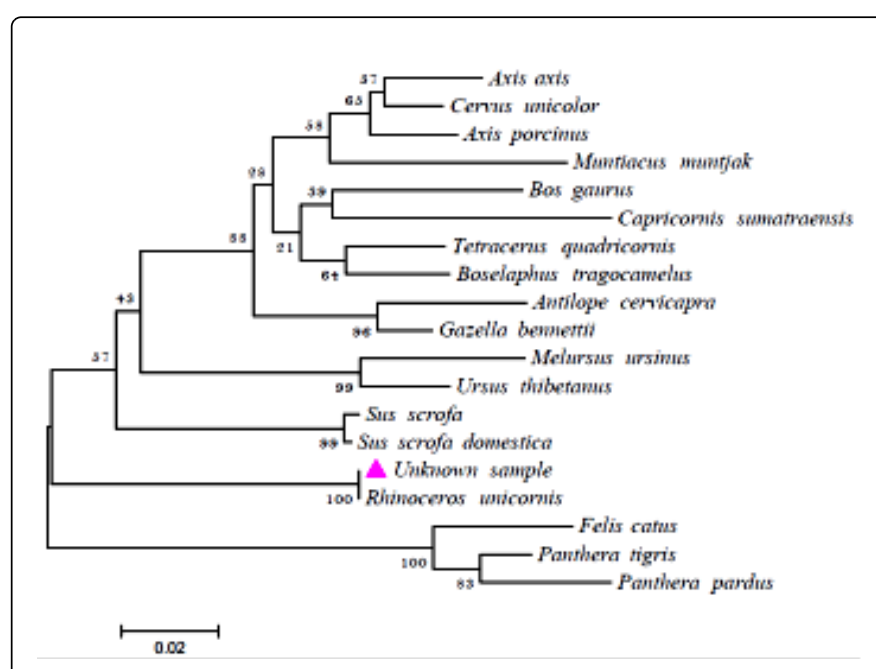

Figure 6: $12 \mathrm{~S}$ rRNA Neighbour-Joining phylogenetic tree showing the relationships of unknown sample with the other nearby species database available in Wildlife Institute of India.

\section{Conclusion}

From the sequence alignment and a score table for the case sample based on Cyt b and 12S rRNA, the source of confiscated sample was found to Rhinoceros unicornis. DNA analysis cannot provide information like age [7] or body parts of the organism concerned. A hierarchy of techniques becomes more effective [58]. Thus, on the basis of genetic analysis result integrated with morphological and microscopic findings sample was ultimately confirmed as a nasal part 
of infantile rhinoceros that bears horn. It is also concluded that infantile rhinoceros horn bears indistinct filamentous unit and laminae with wider filamentous unit space in comparison to mature horn. This is the primary and pioneer work which can be utilized by the scientific community for identification of infantile rhinoceros horn in future.

\section{Acknowledgements}

The authors are deeply indebted to Dr. Siddhartha B. Bajracharya, National Trust for Nature Conservation, Nepal; Mr. Jiwan Pd. Rijal, Executive Director, National Forensic Science Laboratory, Nepal and Dr. Y.V. Jhala, Wildlife Institute of India, Dehradun, India for their necessary steps to arrange the wildlife DNA forensic training after that genetic examination of sample was made possible. We thank Ajit Kumar, Ved P. Kumar and Madhanraj of WII, India and Nanda Kumar Aryal, National Forensic Science laboratory, Nepal for their leading assistance.

\section{References}

1. Robert J (2000) Dossier traffic animal: la Mafia a l'assault de la nature. Terre Sauvage 155: 35-50.

2. Karlsson AO, Holmlud G (2007) Identification of mammal species using species-specific DNA pyrosequencing. Forensic Sci Int 173: 16-20.

3. Linacre A, Tobe SS (2011) An overview to the investigative approach to species testing in wildlife forensic science. Investing Genet 2:2.

4. Hey J (2001) The mind of the species problem. Trends Ecol Evol 16: 326-329.

5. Verma SK, Singh L (2003) Novel universal primers establish identity of an enormous number of animal species for forensic application. Molecular Ecology Notes 3: 28-31.

6. Gupta SK (2012) DNA wildlife forensics: Present and future. J Forensic Res 3: 103.

7. Ogden R, Dawnay N, McEwing R (2009) Wildlife DNA forensicsbridging the gap between conservation genetics and law enforcement. Endang Spec Res 9: 179-195.

8. Tobe SS, Linacre AMT (2008) A multiplex assay to identify 18 European mammal species from mixtures using the mitochondrial cytochrome $b$ gene. Electrophoresis 29: 340-347.

9. Gaur A, Singh CS, Sreenivas A, Singh L (2012) DNA-based identification of a snake in a wine bottle using universal primers: A case of mistaken identity. Forensic Sci Int 214: 51-53.

10. Sahajpal V, Goyal SP (2010) Identification of a forensic case using microscopy and forensically informative nucleotide sequencing (FINS): A case study of small Indian civet (Viverricula indica). Sci Justice 50: 94-97.

11. Fang SG, Wan QH (2002) A genetic fingerprinting test for identifying carcasses of protected deer species in China. Biol Conserv 103: 371-373.

12. Verma SK, Prasad K, Nagesh N, Sultana M, Singh L (2003) Was elusive carnivore a panther? DNA typing of faeces reveals the mystery. Forensic Sci Int 137: 16-20

13. Wan QH, Fang SG (2003) Application of species-specific polymerase chain reaction in the forensic identification of tiger species. Forensic Sci Int 131: 75-78.

14. Lorenzini R (2005) DNA forensics and the poaching of wildlife in Italy: a case study. Forensic Sci Int 153: 218-221.

15. Gupta SK, Verma SK, Singh L (2005) Molecular insight into a wildlife crime: the case of a peafowl slaughter. Forensic Sci Int 154: 214-217.

16. An J, Lee MY, Min MS, Lee MH, Lee H (2007) A molecular genetic approach for species identification of mammals and sex determination of birds in a forensic case of poaching from South Korea. Forensic Sci Int 167: 59-61.
17. Tsai LC, Huang MT, Hsiao CT, Lin AC, Chen SJ, et al. (2007) Species identification of animal specimens by cytochrome $b$ gene. Forensic Science Journal 6: 63-65.

18. Marin JC, Saucedo CE, Corti P, Gonzalez BA (2009) Application of DNA forensic techniques for identifying poached guanacos (Lama guanicoe) in Chilean Patagonia. J Forensic Sci 54: 1073-1076.

19. Caniglia R, Fabbri E, Greco C, Galaverni M, Randi E (2010) Forensic DNA against wildlife poaching: Identification of a serial wolf killing in Italy. Forensic Sci Int: Genetics 4: 334-338.

20. Gupta SK, Kumar A (2014) Molecular identification of man-eating carnivores from scat samples. Conservation Genet Resour 6: 271-274

21. Hsieh HM, Huang LH, Tsai LC, Kuo Y, Meng HH, et al. (2003) Species identification of rhinoceros horns using the cytochrome $b$ gene. Forensic Sci Int 136: 1-11.

22. Jha DK, Kshetry NT, Pokharel BR, Panday R, Aryal NK (2016) A Comparative study of some morphological and microscopic identifying features of genuine Rhino (Rhinoceros unicornis) Horns and Fake Horns. J Forensic Res 6: 315.

23. Rijal JP, Jha DK, Shakya HR (2004) Forensic application of hair comparison, Proceedings of IV National Conference on Science and Technology. pp: 1189-1194.

24. Gupta SK, Kumar A, Hussain SA (2013) Extraction of PCR-amplifiable DNA from a variety of biological samples with uniform success rate. Conservation Genetics Res 5: 215-217.

25. Kocher TD, Thomas WK, Meyer A, Edwards SV, Paabo S, et al. (1989) Dynamics of Mitochondrial DNA Evolution in Animals: Amplification and Sequencing with Conserved Primers. Proceeding of National Academy of Sciences, USA, 86: 6196-6200.

26. Gupta SK, Sharma CP, Singh L (2014) DNA typing established as an unambiguous tool for species identification in a dispute case. Forensic Science Journal 13: 9-14.

27. Hall TA (1999) BioEdit: a user-friendly biological sequence alignment editor and analysis program for windows 95/98/NT. Nucleic Acids Symposium Series 41: 95-98.

28. Altschul SF, Gish W, Miller W, Myers EW, Lipman DJ (1990) Basic local alignment search tool. J Mol Biol 215: 403-410.

29. Saitou N, Nei M (1987) The neighbor-joining method: A new method for reconstructing phylogenetic trees. Mol Biol Evol 4: 406-425.

30. Tamura K, Peterson D, Peterson N, Stecher G, Nei M, et al. (2011) Molecular Evolutionary Genetics Analysis using Maximum Likelihood, Evolutionary Distance, and Maximum Parsimony Methods. Mol Biol Evol 28: 2731-2739.

31. Hieronymus TL, Witmer LM (2004) Rhinoceros horn attachment: anatomy and histology of a dermally influenced bone rugosity. J Morphol 260: 298.

32. Kingdon J, Happold D, Butynski T, Hoffmann M, Happold M, et al. (2013) Carnivores, Pangolins, Equids and Rhinoceroses. In: Mammals of Africa. Bloomsbury Publishing London, UK.

33. Pienaar DJ, Hall-Martin AJ, Hitchnis PM (1991) Horn growth rates of free-ranging white and black rhinoceros. Koedoe 34: 97-105.

34. Bahuguna A, Sahajpal V, Goyal SP, Mukherjee SK, Thakur V (2010) Species identification from guard hair of selected Indian mammals A reference guide. Wildlife Institute of India, India.

35. Brown WM, George Jr. M, Wilson AC (1979) Rapid evolution of animal mitochondrial DNA. Proc Natl Acad Sci USA 76: 1967-1971.

36. Wilson AC, Cann RL, Carr SM, George M, et al. (1985) Mitochondrial DNA and two perspectives on evolutionary genetics. Biol J Linn Soc 26: 375-400.

37. Carracedo A, Bar W, Lincoln P, Mayr W, Morling N, et al. (2000) DNA commission of the international society for forensic genetics: guidelines for mitochondrial DNA typing. Forensic Sci Int 110: 79-85.

38. Pereira SL (2000) Mitochondrial genome organization and vertebrate phylogenetics. Genet Mol Biol 23: 745-752 
Citation: Jha DK, Gupta SK, Kshetry NT, Panday R, Pokharel BR (2017) A Pioneer Case Study on Identification of Infant Rhinoceros Horn. J

Page 6 of 6

39. Johnson RN, Wilson-Wilde L, Linacre A (2014) Current and future directions of DNA in wildlife forensic science. Forensic Sci Int Genet 10: $1-11$.

40. Altschul S, Madden T, Schaffer A, Zhang J, Zhang Z, et al. (1997) Gapped BLAST and PSI-BLAST: a new generation of protein database search programs. Nucleic Acids Res 25: 3389- 3402.

41. Baker CS, Palumbi SR (1994) Which whales are hunted-a molecular genetic approach to monitoring whaling. Science 265: 1538-1539.

42. Parson W, Pegoraro K, Neiderstatter H, Foger M, Steinlechner M (2000) Species identification by means of cytochrome $b$ gene. Int J Legal Med 114: 23-28.

43. Branicki W, Kupiec T, Pawlowski R (2003) Validation of cytochrome b sequence analysis as a method of species identification. J Forensic Sci 48 : 83-87.

44. Paule L, Krajmerová D, Romšáková I, Nedelová L, Slamečka J (2012) Wildlife Forensics genetics-tool for controlling poaching. Internationa symposium on hunting, Modern aspects of sustainable management of game population, Zemun-Belgrade, Serbia pp: 22-24.

45. Caine L, Lima G, Pontes L, Abrantes D, Pereira M, et al. (2006) Species identification by cytochrome $\mathrm{b}$ gene: Casework sample. International Congress Series 1288: 145-147.

46. Avise JC (1993) Molecular markers, natural history and evolution. Chapman and Hall, New York, Uk.

47. Roman J, Bowen BW (2003) The mock turtle syndrome: genetic identification of turtle meat purchased in the south-eastern United States of America. Anim Conserv 3: 61-65.

48. Holder M, Lewis PO (2003) Phylogeny estimation: traditional and Bayesian approaches. Nat Rev Genet 4: 275-284.

49. Terol J, Mascarell R, Fernandez-Pedrosa V, Perez-Alonso M (2002) Statistical validation of the identification of tuna species: bootstrap analysis of mitochondrial DNA sequences. J Agric Food Chem 50: 963-969.

50. Wong KL, Wang J, But PPH, Shaw PC (2004) Application of cytochrome b DNA sequences for the authentication of endangered snake species. Forensic Sci Int 139: 49-55

51. Kumar VP, Kumar D, Goyal SP (2014) Wildlife DNA forensic in curbing illegal wildlife trade: Species identification from seizures. Int J Forensic Sci Pathol 2: 38-42

52. Linacre A, Gusmao L, Hecht W, Hellmann AP, Mayr WR, et al. (2011) ISFG: recommendations regarding the use of non-human (animal) DNA in forensic genetic investigations. Forensic Sci Int Genet 5: 501-505.

53. Dawnay N, Ogden R, McEwing R, Carvalho GR, Thorpe RS (2007) Validation of the barcoding gene COI for use in forensic genetic species identification. Forensic Sci Int 173: 1-6.

54. Groenenberg DSJ, Neubert E, Gittenberger E (2011) Reappraisal of the "Molecular phylogeny of Western Palaearctic Helicidae s.l. (Gastropoda: Stylommato-phora)": When poor science meets GenBank. Mol Phylogenet Evol 61: 914-923.

55. Hassanin A, Bonillo C, Nguyen BX, Cruaud C (2010) Comparisons between mitochondrial genomes of the domestic goat (Capra hircus) reveal the presence of numts and multiple sequencing errors. Mitochondrial DNA 21: 68-76.

56. Bidartondo MI, Bruns TD, Blackwell M, Ryberg M (2008) Preserving accuracy in GenBank. Science 319: 1616.

57. Pereira F, Carneiro J, Amorim A (2008) Identification of species with DNA-based technology: Current progress and challenges. Recent Pat DNA Gene Seq. 2: 187-200.

58. Vipin, Sharma V, Sharma CP, Kumar VP, Goyal SP (2016) Pioneer identification of fake tiger claws using morphometric and DNA-based analysis in wildlife forensics in India. Forensic Sci Int 266: 226-233. 